\title{
Cross-reactive antibody to swine influenza A(H3N2) subtype virus in children and adults before and after immunisation with 2010/11 trivalent inactivated influenza vaccine in Canada, August to November 2010
}

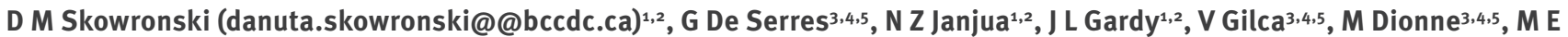

Hamelin 4,5, C Rhéaume 5 , G Boivin 4,5

1. British Columbia Centre for Disease Control, Vancouver, Canada

2. University of British Columbia, Vancouver, Canada

3. Institut National de Santé Publique du Québec (National Institute of Health of Quebec), Québec, Canada

4. Laval University, Quebec, Canada

5. Centre Hospitalier Universitaire de Québec (University Hospital Centre of Quebec), Québec, Canada

Citation style for this article:

Skowronski DM, De Serres G, Janjua NZ, Gardy JL, Gilca V, Dionne M, Hamelin ME, Rhéaume C, Boivin G. Cross-reactive antibody to swine influenza A(H3N2) subtype virus in children and adults before and after immunisation with 2010/11 trivalent inactivated influenza vaccine in Canada, August to November 2010. virus in children and adults before and after immunisation with 2010/11 trivalent inactivated influenza vaccine in Canada, Augu
Euro Surveill. 2012;17(4):pii=20066. Available online: http://www.eurosurveillance.org/ViewArticle.aspx?Articleld=20066

Article published on 26 January 2012

In pre- and post-immunisation sera from children (17120 months-old) and adults (20-59 years-old) immunised with 2010/11 trivalent inactivated influenza vaccine, we assessed age-related patterns of serosusceptibility and vaccine-induced cross-reactive antibodies to a representative swine $\mathrm{H}_{3} \mathrm{~N}_{2}\left(\mathrm{swH}_{3} \mathrm{~N}_{2}\right)$ and a related ancestral human $\mathrm{H}_{3} \mathrm{~N}_{2}$ (A/Sydney/5/1997) influenza virus. Few children but a greater proportion of adults showed pre-immunisation haemagglutination inhibition titres $\geq 40$ to either virus. Titres increased with age among children but decreased in adults. Fewer than $20 \%$ showed a four-fold rise in antibody titres to either virus following immunisation. Further investigation is warranted to guide ongoing risk assessment and response to emerging swine $\mathrm{H}_{3} \mathrm{~N}_{2}$ viruses.

\section{Introduction}

The first documented human infection in North America with an influenza $\mathrm{A}\left(\mathrm{H}_{3} \mathrm{~N}_{2}\right)$ virus of swine origin $\left(\mathrm{swH}_{3} \mathrm{~N}_{2}\right)$ occurred in an Ontario farm worker in 2005 (A/Ontario/RV1273/2005). It involved a swH3 $\mathrm{N}_{2}$ lineage that had entered swine from humans in the mid-1990s $[1,2]$. Sporadic human cases occurred thereafter in the United States (US) and Canada [3,4]. During the latter half of 2011, 12 cases of human infection with a variant of $\mathrm{SwH}_{3} \mathrm{~N}_{2}$ (designated $\mathrm{A}\left(\mathrm{H}_{3} \mathrm{~N}_{2}\right)$ v by the World Health Organization) [5] were identified in the US, primarily among children including some without recognised swine exposure [6]. Recent analysis has shown that $\mathrm{swH}_{3} \mathrm{~N}_{2}$ viruses and zoonotic transmissions to humans, including $\mathrm{A}\left(\mathrm{H}_{3} \mathrm{~N}_{2}\right) \mathrm{v}$, are descendants from a common human influenza virus ancestor, the A/Wuhan/359/1995(H3N2)-like virus [7]. Influenza $A /$ Wuhan/359/1995 has not circulated in humans nor been a component of the trivalent inactivated influenza vaccine (TIV) since 1998, when it was replaced by influenza A/Sydney/5/1997(H3N2) [8-10].

Herein we assess cross-reactive antibody titres to a representative $\mathrm{swH}_{3} \mathrm{~N}_{2}$ virus in sera collected from Canadian children and adults before and after immunisation with the 2010/11 TIV, containing the same vaccine components as the 2011/12 formulation [10].

\section{Methods}

We used a convenience sample of previously collected pre- and post-immunisation sera from children and adults enrolled in 2010/11 TIV immunogenicity trials. Sera had been collected at baseline and 21 to 28 days after the last age-appropriate dose of TIV (Fluviral, GSK, Laval, Quebec, Canada) from Quebec adults in August and September 2010 and from Quebec children in October and November 2010. All had been vaccinated in 2009 with the monovalent ASo3-adjuvanted influenza $A\left(\mathrm{H}_{1} \mathrm{~N}_{1}\right)$ pdmog vaccine (Arepanrix; GSK, Laval, Quebec). The study protocols have been described previously $[11,12]$ and had been approved by the ethics board of the Centre Hospitalier Universitaire de Québec.

Sera were tested for antibodies (i) to influenza $\mathrm{A} /$ Wisconsin/15/2009( $\left.\mathrm{H}_{3} \mathrm{~N}_{2}\right)$, considered antigenically equivalent to the influenza A/Perth/16/2009(H3N2)like component of the 2010/11 (and also 2011/12) northern hemisphere TIV (referred to in this paper as $A /$ Wisconsin), (ii) to a $\mathrm{swH}_{3} \mathrm{~N}_{2}$ virus (A/ferret/ QC/844/2011; F844) isolated from a ferret infected in February 2011 while temporarily housed with swine at the same Quebec animal research facility, and (iii) to influenza A/Sydney/5/97( $\left.\mathrm{H}_{3} \mathrm{~N}_{2}\right)$ as a human influenza ancestor of $\mathrm{swH}_{3} \mathrm{~N}_{2}$ (A/Sydney). Because influenza $A$ / 
Wuhan/359/1995 virus was not readily accessible, A/ Sydney was chosen as the most closely related, available alternative against which to compare age-related trends in cross-reactive antibody levels.

Multiple sequence alignments [13] and BLAST searches [14] generated pairwise identities between F844 gene segments (GenBank accession numbers JQ409334 to JQ409341) and available segments from the following viruses available in GISAID: $\mathrm{A}\left(\mathrm{H}_{3} \mathrm{~N}_{2}\right)$ v (A/Indiana/10/2011(passage $X-1)$ (Indiana State Department of Health Laboratories, Centers for Disease Control and Prevention, sequence authors $B$ Shu, R Garten, S Emery, A Balish, C Smith, J Barnes, S Lindstrom, A Klimov, N Cox), A/Wisconsin (passage $X$-183) (Wisconsin State Laboratory of Hygiene, Centers for Disease Control and Prevention, sequence authors not specified), A/Wuhan/359/1995 (imported from $\mathrm{NCBI}$ ) and A/Sydney (imported from NCBI).

Haemagglutinin (HA) identity was assessed across the HA1 peptide and antigenic regions defined by one scheme of 59 amino acids [7] and an expanded scheme comprising 130 amino acids [15]. Relatedness was further assessed through phylogenies of $\mathrm{HA}$ and neuraminidase (NA) surface proteins of $\mathrm{F} 844, \mathrm{~A}\left(\mathrm{H}_{3} \mathrm{~N}_{2}\right) \mathrm{v}$, other swine and human influenza $\mathrm{A}\left(\mathrm{H}_{3} \mathrm{~N}_{2}\right)$ isolates, and TIV components [16]. The authors gratefully acknowledge the 268 originating and submitting laboratories who contributed sequences used in the phylogenetic analysis to GISAID, and recognise in particular the labs who contributed swine and $A\left(\mathrm{H}_{3} \mathrm{~N}_{2}\right)$ v sequences highlighted in our phylogenetic analysis: Canadian Food Inspection Agency, Centers for Disease Control and Prevention, Indiana State Department of Health Laboratories, lowa State Hygienic Laboratory, Kansas Department of Health and Environment, Maine Health and Environmental Testing Laboratory, Minnesota Department of Health, Pennsylvania Department of Health, Public Health Agency of Canada, and University of Pittsburgh Medical Center Microbiology Lab.

Antibody titres were measured in duplicate by haemagglutination inhibition (HI) as previously described [11]. Turkey red blood cells (RBCs) were used for F844 and A/Wisconsin; guinea pig RBCs were used for A/Sydney. Titres $<10$ were assigned a value of 5 . Scatter plots and Pearson correlation coefficients of natural logarithmtransformed titres were explored. Immunogenicity end points included group GMTs, the ratio of post- versus pre-immunisation GMTs (GMTR), the proportion of participants with $\mathrm{HI}$ titre $\geq 40$ (by convention considered the sero-protective threshold for evaluating vaccine antigens), and the proportion of sero-converting individuals (those showing four-fold increase in post- compared with pre-immunisation titres or from $\mathrm{HI}$ titre $<10$ pre-immunisation to at least 40 post-immunisation) $[17,18]$. Linear regression models assessed trends in GMTs by one-year age interval and the chi-square test was used to compare differences in the proportion of participants with $\mathrm{HI}$ titre $\geq 40$ by age category.

\section{Results}

\section{Participants}

Sera from 138 children were included. The mean/median age of paediatric participants was $63 / 63$ months, with a range of 17 to 120 months. Forty-six children never before immunised against seasonal influenza received two doses of 2010/11 TIV, whereas 91 received a single dose. For one child this information was not available. Eighty children $(58 \%)$ had received at least one prior TIV dose, 24 (17\%) had received at least three doses. Sixty-five adults were included, among whom the mean/median age was 40/39 years, with a range of 20 to 59 years. Of these, $58(89 \%)$ had received TIV previously: $41(71 \%)$ a single dose, $16(28 \%)$ twice and one $(1.7 \%)$ three times previously.

\section{Phylogenetic relatedness}

Phylogenetic analysis established F844 to be representative of circulating $\mathrm{SwH}_{3} \mathrm{~N}_{2}$ viruses with zoonotic potential, including $A\left(\mathrm{H}_{3} \mathrm{~N}_{2}\right) v$ (Figure 1). BLAST indicated the closest match to each F844 segment originated from $\mathrm{swH}_{3} \mathrm{~N}_{2}$ viruses isolated in North America between 2005 and 2010 (pairwise identities 97.998.9\%), with the F844 HA and NA most similar to that of the $\mathrm{A} / \mathrm{swine} / \mathrm{QC} / 382 / 2009$ virus $(98.3 \%$ and $99.1 \%$ pairwise identity, respectively). The closest human $\mathrm{SwH}_{3} \mathrm{~N}_{2} \mathrm{HA}$ was found in A/lowa/16/2009 (97.4\% pairwise identity), and the closest human $\mathrm{SwH}_{3} \mathrm{~N}_{2} \mathrm{NA}$ in $\mathrm{A} /$ Ontario/1252/2007 (98.9\% pairwise identity) (Figure 1).

The human-origin isolate influenza A/Ontario/ RV1273/2005 was among the ten isolates most closely related to F844 for all but the NS segment, further reinforcing zoonotic potential of the F844 strain. F844 does not contain the influenza $A\left(\mathrm{H}_{1} \mathrm{~N}_{1}\right)$ pdmog $M$ gene seen in recent $\mathrm{A}\left(\mathrm{H}_{3} \mathrm{~N}_{2}\right) \mathrm{v}$ isolates, however both $\mathrm{F} 844$ and $\mathrm{A} /$ Indiana/10/2011 (representative $\mathrm{A}\left(\mathrm{H}_{3} \mathrm{~N}_{2}\right)$ v virus) originate from an identical common ancestor and exhibit 93.3\% identity in $\mathrm{HA}_{1}$ peptides and $88 \%$ identity in HA antigenic regions (Table 1). Both viruses show comparable identity to $A / S y d n e y$ in $\mathrm{HA}_{1}$ and antigenic regions, and 27 of the 41 mutations observed in an alignment of F844, A/Indiana/10/2011 and A/Sydney HA1, are common to both F844 and A/Indiana/10/2011.

\section{Immunogenicity and cross-reactivity}

A similar proportion (ca. $35 \%$ ) of children and adults showed a pre-immunisation $\mathrm{HI}$ titre of $\geq 40$ to $\mathrm{A} /$ Wisconsin. There was substantial TIV-induced improvement in the level of antibodies to A/Wisconsin, with ca. $90 \%$ showing $\mathrm{HI}$ titres $\geq 40$ post-immunisation (Table 2 ). For F844 and A/Sydney, only $1 \%$ and $12 \%$ of children, respectively, showed $\mathrm{HI}$ titres $\geq 40$ pre-immunisation whereas approximately half of the adults showed preimmunisation titres $\geq 40$ to these viruses. Immunisation with the 2010/11 TIV increased antibody titres to F844 and $\mathrm{A}$ /Sydney only marginally in children ( $8 \%$ and $19 \%$ sero-converting, respectively) and adults (11\% and $15 \%$ sero-converting, respectively). 
There was a strong correlation between F844 and A/ Sydney titres both pre and post immunisation in children (0.74/0.76) and adults (0.68/0.76) (all p<0.001).
The correlation was less strong between F844 and A/Wisconsin in both children $(0.24(p=0.005) / 0.43$ $(p<0.001))$ and adults $(0.39(p=0.001) / 0.24(p=0.05))$.

\section{FIGURE 1}

Maximum likelihood phylogeny showing location of F844 relative to swine and human swH3N2 viruses and human vaccine strains

Haemagglutinin

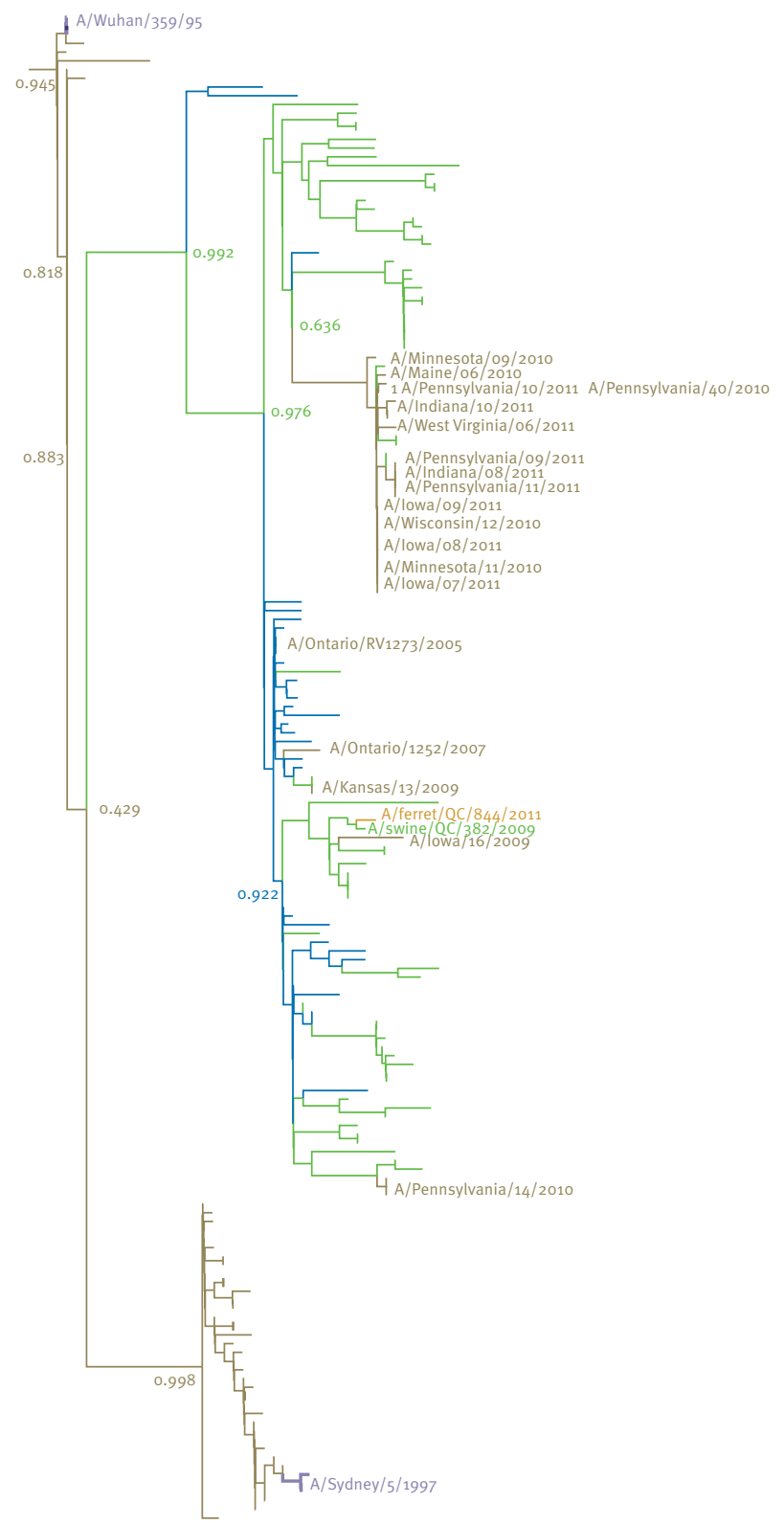

Swine isolate (pre-2008)
Neuraminidase

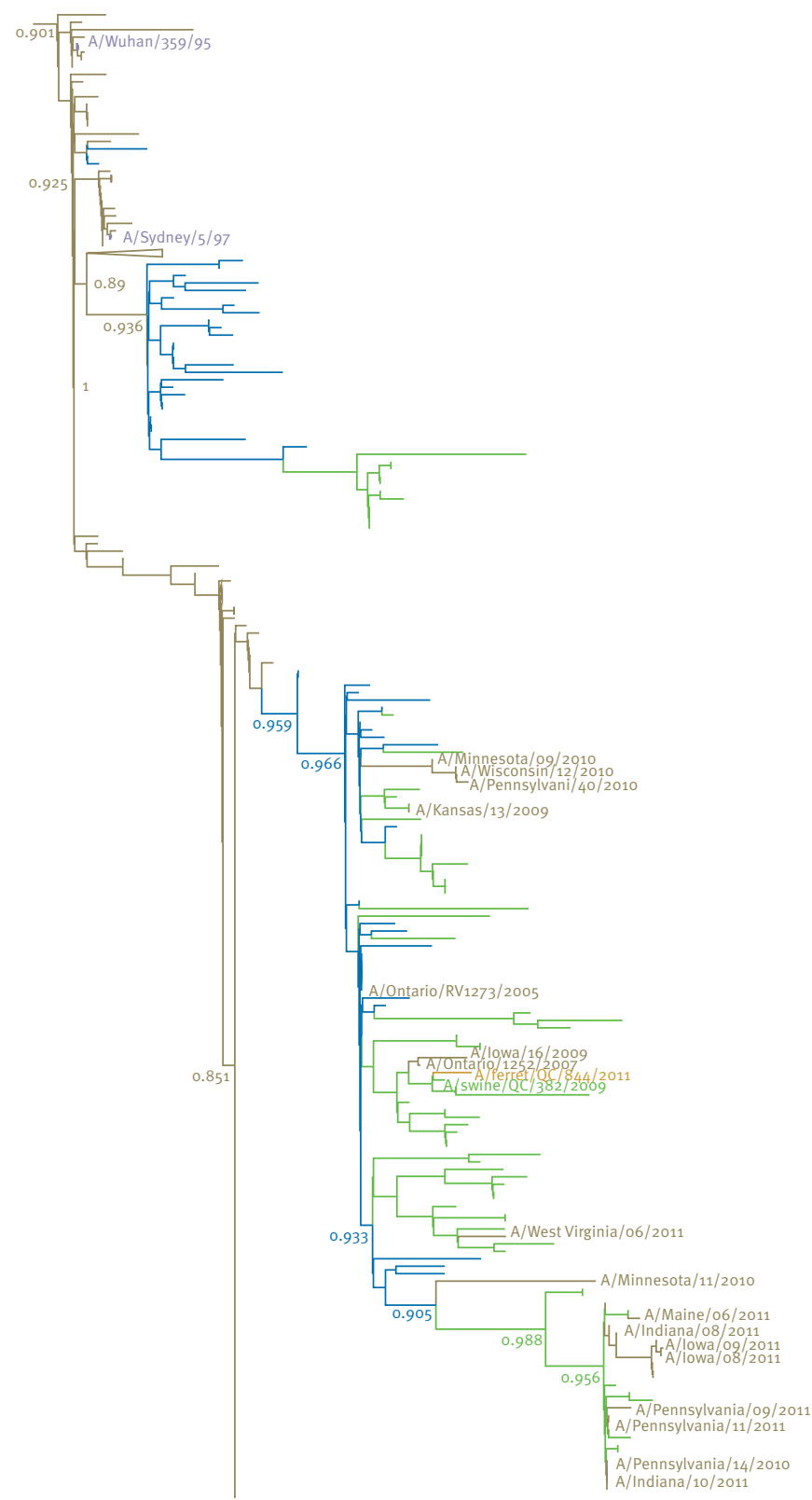

Human isolate $\square$ Vaccine strain $\square$ Study virus

F844: influenza A/ferret/QC/844/2011; swH3N2: influenza $A\left(\mathrm{H}_{3} \mathrm{~N}_{2}\right)$ of swine origin.

The tree was created with FastTree using the JTT evolutionary model and the Shimodara-Hasegawa test of branch support, using 6,932 swine and human influenza $\mathrm{A}\left(\mathrm{H}_{3} \mathrm{~N}_{2}\right)$ haemagglutinin sequences and 6,635 swine and human neuraminidase sequences. Certain branches have been collapsed and labels deleted for ease of viewing.

The authors gratefully acknowledge the 268 originating and submitting laboratories who contributed sequences used in the phylogenetic analysis to GISAID, and recognise in particular the labs who contributed swine and $\mathrm{A}\left(\mathrm{H}_{3} \mathrm{~N} 2\right) \mathrm{v}$ sequences highlighted in our phylogenetic analysis: Canadian Food Inspection Agency, Centers for Disease Control and Prevention, Indiana State Department of Health Laboratories, lowa State Hygienic Laboratory, Kansas Department of Health and Environment, Maine Health and Environmental Testing Laboratory, Minnesota Department of Health, Pennsylvania Department of Health, Public Health Agency of Canada, and University of Pittsburgh Medical Center Microbiology Lab. 
On linear regression, GMTs to all three antigens increased significantly with age pre and post immunisation in the paediatric cohort; conversely in the adult cohort, GMTs decreased significantly with age for F844 and A/Sydney but not A/Wisconsin (Figure 2A/B).

More children five years and older compared to those under five years of age had $\mathrm{HI}$ titres of $\geq 40$, statistically significant for all viruses and time points except the A/ Wisconsin virus at the post-immunisation collection (Table $2 \mathrm{C}$ ). Conversely, antibody titres of $\geq 40$ were less frequent in adults 40 years and older than in younger adults 20-39 years-old, statistically significant for
F844 and A/Sydney both before and after immunisation, but not for $\mathrm{A} /$ Wisconsin (Table $2 \mathrm{C}$ ).

\section{Discussion}

The intent of this investigation was to assess current vulnerability to emerging zoonotic transmissions of swine influenza $\mathrm{H}_{3} \mathrm{~N}_{2}$ viruses. With limited early access to the specific US $A\left(\mathrm{H}_{3} \mathrm{~N}_{2}\right) v$, we used a representative swine influenza virus locally acquired from an infected ferret to explore the likelihood of pre-existing and TIV-induced cross-reactive antibody to swine influenza $\mathrm{A}\left(\mathrm{H}_{3} \mathrm{~N}_{2}\right)$ in children and adults. Although F844 is not a precise match to the specific $A\left(\mathrm{H}_{3} \mathrm{~N}_{2}\right) \mathrm{v}$,

\section{TABLE 1}

Amino acid sequence comparison (\% pairwise identity) of influenza F844, A(H3N2)v and select human H3N2 vaccine components

\begin{tabular}{|c|c|c|c|c|}
\hline & A/ferret/QC/844/2011 & A/Indiana/10/2011 & A/Wuhan/359/1995 & A/Sydney/5/1997 \\
\hline \multicolumn{5}{|c|}{ Haemagglutinin HA1 peptide } \\
\hline A/Indiana/10/2011 & 93.3 & & & \\
\hline A/Wuhan/359/1995 & 91.7 & 90.0 & & \\
\hline A/Sydney/5/1997 & 89.7 & 87.8 & 96.4 & \\
\hline A/Wisconsin/15/2009 & 87.8 & 86.0 & 90.0 & 90.6 \\
\hline \multicolumn{5}{|c|}{ Haemagglutinin antigenic regions (scheme 1$)^{a}$} \\
\hline $\mathrm{A} /$ Indiana/10/2011 & 88.1 & & & \\
\hline A/Wuhan/359/1995 & 81.4 & 83.1 & & \\
\hline A/Sydney/5/1997 & 76.3 & 78.0 & 89.8 & \\
\hline A/Wisconsin/15/2009 & 71.2 & 74.6 & 71.2 & 74.6 \\
\hline \multicolumn{5}{|c|}{ Haemagglutinin antigenic regions (scheme 2$)^{\mathrm{b}}$} \\
\hline $\mathrm{A} /$ Indiana/10/2011 & 88.5 & & & \\
\hline A/Wuhan/359/1995 & 82.3 & 80.0 & & \\
\hline A/Sydney/5/1997 & 78.5 & 76.2 & 92.3 & \\
\hline A/Wisconsin/15/2009 & 76.2 & 73.1 & 77.7 & 80.8 \\
\hline \multicolumn{5}{|l|}{ Neuraminidase NA } \\
\hline $\mathrm{A} /$ Indiana/10/2011 & 93.6 & & & \\
\hline A/Wuhan/359/1995 & 93.4 & 91.3 & & \\
\hline A/Sydney/5/1997 & 93.8 & 91.7 & 98.7 & \\
\hline A/Wisconsin/15/2009 & 92.3 & 90.8 & 93.2 & $\mathrm{~N} / \mathrm{A}$ \\
\hline \multicolumn{5}{|l|}{ Matrix $M_{1}$} \\
\hline $\mathrm{A} /$ Indiana/10/2011 & 93.5 & & & \\
\hline A/Wuhan/359/1995 & 94.7 & 92.9 & & \\
\hline A/Sydney/5/1997 & 95.1 & 92.1 & 97.6 & \\
\hline A/Wisconsin/15/2009 & 95.5 & 94.8 & 95.6 & 95.6 \\
\hline \multicolumn{5}{|l|}{ Matrix $\mathrm{M}_{2}$} \\
\hline A/Indiana/10/2011 & 83.8 & & & \\
\hline A/Wuhan/359/1995 & 82.5 & 87.0 & & \\
\hline A/Sydney/5/1997 & 82.5 & 83.3 & 95.8 & \\
\hline A/Wisconsin/15/2009 & 81.3 & 84.8 & 86.6 & 88.4 \\
\hline
\end{tabular}

a Scheme 1: 59 amino acids [7]

b Scheme 2: 130 amino acids [15].

F844: influenza A/ferret/QC/844/2011, a swine influenza $A\left(\mathrm{H}_{3} \mathrm{~N}_{2}\right)$ virus isolated from a Quebec ferret.

$A /$ Indiana/10/2011: a representative of the variant swine influenza $A\left(\mathrm{H}_{3} \mathrm{~N}_{2}\right)$ virus $\left(A\left(\mathrm{H}_{3} \mathrm{~N}_{2}\right) \mathrm{v}\right)$.

$\mathrm{A} /$ Wuhan/359/1995: a human influenza $\mathrm{A}\left(\mathrm{H}_{3} \mathrm{~N}_{2}\right)$ virus and component of the northern hemisphere vaccines of $1996 / 97$ and $1997 / 98$.

$\mathrm{A} /$ Sydney/5/1997: a human influenza $\mathrm{A}\left(\mathrm{H}_{3} \mathrm{~N}_{2}\right)$ virus and component of the northern hemisphere vaccines of $1998 / 99$ and $1999 / 00$.

A/Wisconsin/15/2009: antigenically equivalent to the influenza A/Perth/16/2009(H3N2) component of the $2010 / 11$ and $2011 / 12$ northern hemisphere vaccines.

The authors acknowledge the Centers for Disease Control and Prevention, the Indiana State Department of Health Laboratories, and the Wisconsin State Laboratory of Hygiene, who submitted sequences used in this table to GISAID. 
it is representative of viruses of swine-origin that have infected humans since 2005 and continue to circulate in North American pigs. F844 and $\mathrm{A}\left(\mathrm{H}_{3} \mathrm{~N}_{2}\right)$ v showed similar pairwise identity to A/Sydney for the most relevant HA surface protein and, in combination, our findings for F844 and A/Sydney may frame major trends in cross-reactive antibody titres to $\mathrm{swH}_{3} \mathrm{~N}_{2}$ by age. By comparing with antibodies to human viruses that are closely related but ancestral (A/Sydney) and with human strains that are antigenically distant but more recent (A/Wisconsin), we sought to better contextualise and inform age-related observations.

\section{TABLE 2}

Haemagglutination inhibition antibody levels to select influenza A(H3N2) strains before and after 2010/11 trivalent inactivated influenza vaccination, Quebec, August-November 2010 ( $\mathrm{n}=203)$

A. Children 17-120 months of age $(\mathrm{N}=138)$

\begin{tabular}{|c|c|c|c|c|}
\hline $\mathrm{H}_{3} \mathrm{~N}_{2}$ virus strain & $\begin{array}{c}\text { GMT } \\
(95 \% \mathrm{Cl})\end{array}$ & $\begin{array}{c}\text { Proportion with } \mathrm{HI} \text { titre } \geq 40 \\
\%(95 \% \mathrm{Cl})\end{array}$ & GMTR & $\begin{array}{c}\text { Proportion sero-converting } \\
\%(95 \% \mathrm{Cl})\end{array}$ \\
\hline \multicolumn{5}{|c|}{ A/Wisconsin $/ 15 / 2009^{b}$} \\
\hline Pre vaccination & $18.7(14.5-24.3)$ & $37(29-45)$ & - & - \\
\hline Post vaccination & $229.7(176.6-298.8)$ & $89(84-94)$ & 12.28 & $80(74-87)$ \\
\hline \multicolumn{5}{|l|}{ A/Sydney/5/1997 } \\
\hline Pre-vaccination & $8.5(7-10.2)$ & $12(7-18)$ & - & - \\
\hline Post vaccination & $15.5(12.1-19.8)$ & $30(23-38)$ & 1.82 & $19(12-25)$ \\
\hline \multicolumn{5}{|c|}{$\mathrm{A} /$ Ferret/QC/844/2011 ${ }^{\mathrm{d}}$} \\
\hline Pre vaccination & $5.6(5.3-6)$ & $1(0-3)$ & - & - \\
\hline Post vaccination & $7.7(6.7-8.8)$ & $9(5-14)$ & 1.38 & $8(3-13)$ \\
\hline
\end{tabular}

\section{B. Adults 20-59 years of age $(\mathrm{N}=65)$}

\begin{tabular}{|c|c|c|c|c|}
\hline $\mathrm{H}_{3} \mathrm{~N}_{2}$ virus strain & $\begin{array}{c}\text { GMT } \\
(95 \% \mathrm{Cl})\end{array}$ & $\begin{array}{c}\text { Proportion with HI titre } \geq 40 \\
\%(95 \% \mathrm{Cl})\end{array}$ & GMTR & $\begin{array}{c}\text { Proportion sero-converting } \\
\%(95 \% \mathrm{Cl})\end{array}$ \\
\hline \multicolumn{5}{|c|}{ A/Wisconsin/15/2009 ${ }^{b}$} \\
\hline Pre vaccination & $21.8(16.2-29.3)$ & $35(23-47)$ & - & - \\
\hline Post vaccination & $127.9(94.4-173.3)$ & $89(81-97)$ & 5.87 & $65(53-77)$ \\
\hline \multicolumn{5}{|l|}{ A/Sydney/5/1997 } \\
\hline Pre vaccination & $24(18.2-31.5)$ & $45(32-57)$ & - & - \\
\hline Post vaccination & $41.7(31.5-55.3)$ & $62(49-74)$ & 1.74 & $15(6-24)$ \\
\hline \multicolumn{5}{|c|}{ A/Ferret/QC/844/2011 } \\
\hline Pre vaccination & $31.3(21.9-44.8)$ & $54(41-66)$ & - & - \\
\hline Post vaccination & $50.6(35.9-71.3)$ & $66(54-78)$ & 1.62 & $11(3-19)$ \\
\hline
\end{tabular}

\section{Proportion with antibody titre $\geq 40$, by age category}

\begin{tabular}{|c|c|c|c|c|c|c|}
\hline \multirow[b]{2}{*}{$\mathrm{H}_{3} \mathrm{~N}_{2}$ virus strain } & \multicolumn{3}{|c|}{$\begin{array}{l}\text { Children aged } 17-120 \text { months } \\
n(\% ; 95 \% \mathrm{Cl})\end{array}$} & \multicolumn{3}{|c|}{$\begin{array}{l}\text { Adults aged } 20-59 \text { years } \\
\qquad \mathrm{n}(\% ; 95 \% \mathrm{Cl})\end{array}$} \\
\hline & $\begin{array}{l}<5 \text { years } \\
N=63\end{array}$ & $\begin{array}{c}\geq 5 \text { years } \\
N=75\end{array}$ & $P$ & $\begin{array}{c}20-39 \text { years } \\
N=33\end{array}$ & $\begin{array}{c}\geq 40 \text { years } \\
\quad N=32\end{array}$ & $P$ \\
\hline \multicolumn{7}{|c|}{ A/Wisconsin/15/2009b } \\
\hline Pre vaccination & $14(22 ; 12-33)$ & $37(49 ; 38-61)$ & 0.001 & $15(45 ; 28-63)$ & $8(25 ; 10-40)$ & 0.09 \\
\hline Post vaccination & $53(84 ; 75-93)$ & $70(93 ; 88-99)$ & 0.08 & $31(94 ; 86-100)$ & $27(84 ; 71-97)$ & 0.21 \\
\hline \multicolumn{7}{|l|}{ A/Sydney/5/1997 ${ }^{c}$} \\
\hline Pre vaccination & $0(0)$ & $17(23 ; 13-32)$ & - & $19(58 ; 40-75)$ & $10(31 ; 15-48)$ & 0.03 \\
\hline Post vaccination & $7(11 ; 3-19)$ & $35(47 ; 35-58)$ & $<0.0001$ & $25(76 ; 61-91)$ & $15(47 ; 29-65)$ & 0.02 \\
\hline \multicolumn{7}{|c|}{ A/Ferret/QC/844/2011 } \\
\hline Pre vaccination & $0(0)$ & $2(3 ; 0-6)$ & - & $28(85 ; 72-97)$ & $7(22 ; 7-37)$ & $<0.0001$ \\
\hline Post vaccination & $1(2 ; 0-5)$ & $12(16 ; 8-24)$ & 0.004 & $31(94 ; 86-100)$ & $12(38 ; 20-55)$ & $<0.0001$ \\
\hline
\end{tabular}

$\mathrm{Cl}$ : confidence interval; GMT: geometric mean titre; GMTR: ratio of post-/pre-immunisation GMTs; HI: haemagglutination ininhibition.

Sero-conversion defined as four-fold increase in post- versus pre-immunisation titres or from HI titre $<10$ pre immunisation to at least 40 post immunisation.

a Post-immunisation results for age-appropriate dose measured 3-4 weeks following one dose for previously immunised and following two doses for unimmunised children.

b Antigenically equivalent to the $\mathrm{A} /$ Perth/16/2009( $\left.\mathrm{H}_{3} \mathrm{~N}_{2}\right)$-like vaccine component of the 2010/11 and 2011/12 trivalent inactivated influenza vaccine.

Guinea pig red blood cells (RBCs) used; for all other viruses turkey RBCs.

d $\mathrm{N}=137$ due to insufficient sera. 
The limitations of our approach warrant consideration. Some laboratory variability in influenza antibody assay results is widely recognised. It should also be recognised that titres measured in $\mathrm{HI}$ assays, unlike microneutralisation, do not necessarily represent functional antibodies and the threshold of 40 conventionally applied as indicative of sero-protection may not predict immunity to zoonotic infections [17-21]. In general, HI is thought to overestimate cross-reactive heterologous versus homologous responses, and given that $\mathrm{A}\left(\mathrm{H}_{3} \mathrm{~N}_{2}\right)$ $v$ is slightly more divergent from ancestral strains in its $\mathrm{HA}_{1}$ than is $\mathrm{F} 844$, there may be additional reason to consider our results optimistic [18-21]. Conversely, other markers such as cell-mediated immunity may also contribute to protection but were not assessed. We have highlighted that $\mathrm{F} 844$ and $\mathrm{A}\left(\mathrm{H}_{3} \mathrm{~N}_{2}\right) \mathrm{v}$ are not precise antigenic matches and that $\mathrm{A} / \mathrm{Sydney}$ is not the direct precursor of either $\mathrm{swH}_{3} \mathrm{~N}_{2}$ virus. Differences in absolute titres or proportions by age may be expected although the major age-related trends we highlight should still apply. A specific $\mathrm{swH}_{3} \mathrm{~N}_{2}$ virus has not yet established sustained community transmission. Further mutation, reassortment or other virus evolution is still possible and we cannot predict which $\mathrm{swH}_{3} \mathrm{~N}_{2}$ virus may ultimately assert itself in the human population. For the purpose of ongoing risk assessment, it thus remains prudent to consider major trends rather than precise results for a particular $\mathrm{swH}_{3} \mathrm{~N}_{2}$ virus.
Finally, the small sample size, limited age categories and geographic representation of included sera must also be taken into account in interpreting our findings.

With these caveats in mind, our findings present several signals worthy of further investigation. Only few children younger than 10 years had cross-reactive antibodies to $\mathrm{SwH}_{3} \mathrm{~N}_{2}$ before or after immunisation, and when present, these antibodies were at low levels. We found more adults with cross-reactive antibody titres $\geq 40$ against $\mathrm{swH}_{3} \mathrm{~N}_{2}$, although GMTs were still not very high. The 2010/11 TIV only marginally increased cross-reactive antibody levels in both children and adults. Given that the same vaccine components have been used in the 2011/12 TIV, these 2010/11 findings will likely also apply to 2011/12 [10]. As noted above, however, the clinical implications of low-level crossreactive $\mathrm{HI}$ antibodies are uncertain.

We observed greater likelihood of cross-reactive antibodies with increasing paediatric age but a paradoxical and unexpected pattern of decrease with increasing age in adults. We cannot address the level of crossreactive antibodies in children 10 to 19 years of age or the elderly because they were not included in the original immunogenicity trials from which these sera were drawn. However, the pattern of decrease shown across young and middle-aged adults suggests that antibody

\section{FIGURE 2}

Antibody titres pre- and post immunisation with 2010/11 trivalent inactivated influenza vaccine, by age, for influenza A/ Wisconsin/15/2009, A/Sydney/5/1997 and A/ferret/QC/844/2011, Quebec, August-November 2010 (n=203)

\section{A. Children}
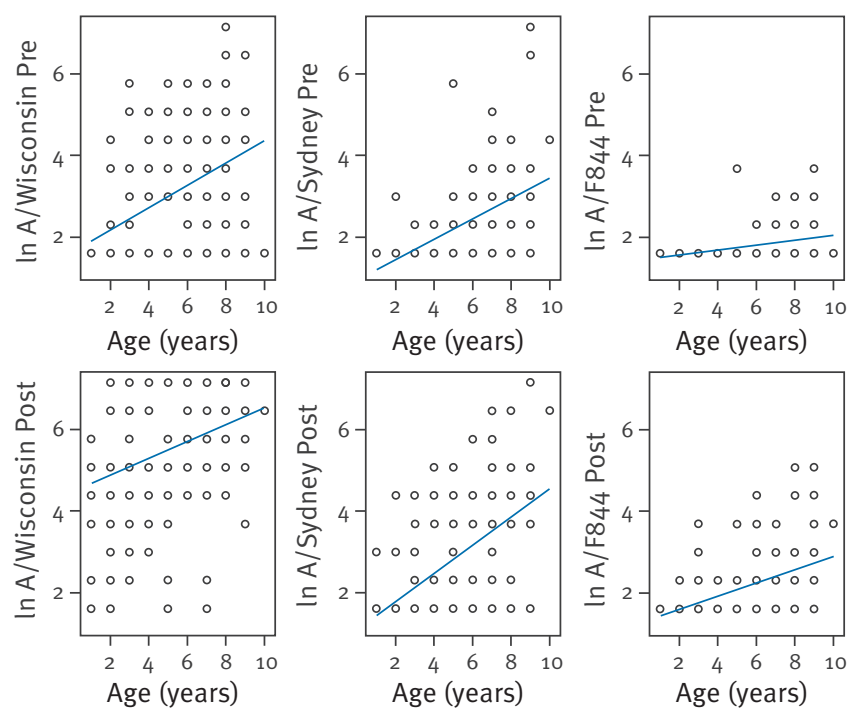

Linear regression $\beta(95 \% \mathrm{Cl})$ and $p$ value for effect of age on geometric mean titre pre- and post-immunisation, children:

A/Wisconsin pre-immunisation: 1.32 (1.19-1.45), P<0.001; postimmunisation: 1.23 (1.11-1.36), $\mathrm{P}=0.0002$

A/Sydney pre-immunisation: 1.28 (1.2-1.37), P<0.001; postimmunisation: $1.41(1.3-1.54), P<0.001$

A/F844 pre-immunisation: 1.06 (1.04-1.09), P<0.001; postimmunisation: $1.18(1.12-1.24), P<0.001$
B. Adults
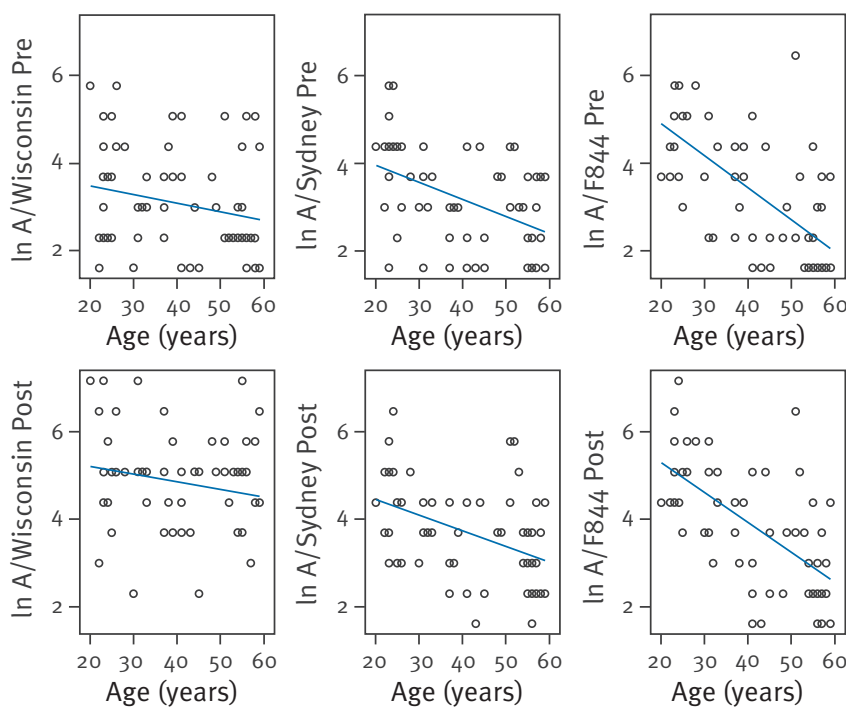

Linear regression $\beta(95 \% \mathrm{Cl})$ and $p$ value for effect of age on geometric mean titre pre-/post-immunisation, adults:

A/Wisconsin pre-immunisation: -1.02 (-1.04 to 1$), P=0.08$; postimmunisation: $-1.02(-1.04$ to 1.01$), P=0.14$

A/Sydney pre-immunisation: -1.04 (-1.06 to -0.98), P<.0001; postimmunisation: $-1.04(-1.06$ to -0.98$), P=0.0005$

A/F844 pre-immunisation: -1.08 (-1.1 to -0.95), P<.0001; postimmunisation: -1.07 (-1.09 to -0.95$),$ P<.0001 
titres may also be low in the elderly and this should prompt further evaluation.

The immuno-epidemiologic reasons for a pattern of declining cross-reactivity despite greater likelihood of cumulative exposure to influenza $\mathrm{A}\left(\mathrm{H}_{3} \mathrm{~N}_{2}\right)$ viruses with adult age may be worth reflection. The closest ancestor of $\mathrm{swH}_{3} \mathrm{~N}_{2}$ viruses, including $\mathrm{A}\left(\mathrm{H}_{3} \mathrm{~N}_{2}\right) \mathrm{v}$, circulated in human populations approximately 15 years ago and is represented in our paper by A/Sydney/5/1997 [7]. Very young participants in this study would not have been exposed to these ancestral viruses in the mid- and late 1990s, and their lack of antibodies is therefore not unexpected; conversely, most adult participants should have been exposed. Allowing for the greatest likelihood of first influenza exposure and infection at pre-school or school age, higher titres to ancestral and related $\mathrm{swH}_{3} \mathrm{~N}_{2}$ viruses 15 years later in young but not older adults may be consistent with the theory of robust and preferential recall of antibody to first-infecting viruses with subsequent and cumulative infections [22]. A similar phenomenon has been invoked to explain the higher pre-pandemic titres to the influenza $A\left(\mathrm{H}_{1} \mathrm{~N}_{1}\right)$ pdmog virus found in the very old even decades after their priming exposure to a related but historic $\mathrm{H}_{1} \mathrm{~N}_{1}$ virus in their childhood [23]. Following the same concept, lower titres to A/Sydney and related $\mathrm{swH}_{3} \mathrm{~N}_{2}$ virus in middle-aged compared with younger adults may signal different original priming experiences. However, it was not the intent of this paper to elucidate immunological mechanisms; these concepts remain speculative and require specific hypothesis testing.

Overall, our results suggest broad susceptibility to swine-origin $\mathrm{H}_{3} \mathrm{~N}_{2}$ infection in young children, consistent with early epidemiologic features of $A\left(\mathrm{H}_{3} \mathrm{~N}_{2}\right)$ $v$ in the US. Susceptibility may also increase with age in adults. Given the recognised potential for children to amplify influenza spread in the community [24], and the greater vulnerability of older adults to severe outcomes of $\mathrm{H}_{3} \mathrm{~N}_{2}$ infection generally [25], these signals warrant further investigation to guide ongoing risk assessment and response to emerging $\mathrm{swH}_{3} \mathrm{~N}_{2}$ viruses. The $\mathrm{H}_{3} \mathrm{~N}_{2}$ subtype of swine-origin influenza may show a different age-related pattern of risk in the human population compared to the $\mathrm{H}_{1} \mathrm{~N}_{1}$ subtype that caused the 2009 pandemic and recommendations may need to be adjusted accordingly. We observed little TIV-induced improvement in cross-reactive antibodies suggesting that a specific candidate vaccine would be required in the event of further zoonotic transmission and epidemic spread of $\mathrm{swH}_{3} \mathrm{~N}_{2}$ virus. Additional studies should explore age-related and vaccine-induced effects across a greater age and geographic span, applying multiple immunogenicity assays (HI, microneutralisation, cell-mediated immune markers) and swine-origin influenza $\mathrm{A}\left(\mathrm{H}_{3} \mathrm{~N}_{2}\right)$ viruses, including $\mathrm{A}\left(\mathrm{H}_{3} \mathrm{~N}_{2}\right) \mathrm{v}$.
Acknowledgments

The authors appreciate the helpful review and comments provided prior to submission by Drs. David Scheifele and Brian Ward of the Public Health Agency of Canada-CIHR Research Network (PCIRN). We also gratefully acknowledge the authors, originating and submitting laboratories of the sequences from GISAID's EpiFlu Database used in the phylogenetic analysis. Adult sera used in this study had been collected as part of a controlled clinical trial, registration number: NCT0114009. This study was funded by the Quebec Ministry of Health, the Public Health Agency of Canada-CIHR Research Network (PCIRN), the Michael Smith Foundation for Health Research, and the institutes of Investigators.

\section{Competing interests}

GD has received research grants from GlaxoSmithKline (GSK) and Sanofi Pasteur, VG from GSK and Merck, MD from GSK, Merck and Wyeth (now Pfizer). GB has received research grant funding from GSK. No other authors have competing interests to declare.

\section{References}

1. Olsen CW, Karasin Al, Carman S, Li Y, Bastien N, Ojkic D, et al. Triple reassortant $\mathrm{H}_{3} \mathrm{~N}_{2}$ influenza A viruses, Canada, 2005. Emerg Infect Dis. 2006;12(7):1132-5.

2. Myers KP, Olsen CW, Gray GC. Cases of swine influenza in humans: a review of the literature. Clin Infect Dis. 2007;44(8):1084-8.

3. Robinson JL, Lee BE, Patel J, Bastien N, Grimsrud K, Seal $\mathrm{RF}$, et al. Swine influenza $\left(\mathrm{H}_{3} \mathrm{~N}_{2}\right)$ infection in a child and possible community transmission, Canada. Emerg Infect Dis. 2007;13(12):1865-70.

4. Centers for Disease Control and Prevention (CDC). Swine-origin influenza $\mathrm{A}\left(\mathrm{H}_{3} \mathrm{~N}_{2}\right)$ virus infection in two children-Indiana and Pennsylvania, July-August 2011. MMWR Morb Mortal Wkly Rep. 2011;60(35):1213-5.

5. World Health Organization (WHO). Standardization of terminology for the variant $\mathrm{A}\left(\mathrm{H}_{3} \mathrm{~N}_{2}\right)$ virus recently infecting humans. Joint Announcement of FAO, OIE and WHO. Geneva: WHO; 23 Dec 2011. Available from: http://www.who.int/ influenza/gisrs_laboratory/terminology_ahzn2v/en/index.html

6. Centers for Disease Control and Prevention (CDC). Update: influenza $A\left(\mathrm{H}_{3} \mathrm{~N}_{2}\right) v$ transmission and guidelines-five states, 2011. MMWR Morb Mortal Wkly Rep. 2012;60:1741-4.

7. Lina B, Bouscambert M, Enouf V, Rousset D, Valette M, van der Werf S. S-OtrH3 2 viruses: use of sequence data for description of the molecular characteristics of the viruses and their relatedness to previously circulating $\mathrm{H}_{3} \mathrm{~N}_{2}$ human viruses. Euro Surveill.2011;16(50):pii=20039. Available from: http://www.eurosurveillance.org/ViewArticle. aspx?Articleid $=20039$

8. Recommended composition of influenza virus vaccines for use in the 1997-1998 season. Wkly Epidemiol Rec. 1997;72(9):57-61.

9. Recommended composition of influenza virus vaccines for use in the 1998-1999 season. Wkly Epidemiol Rec. 1998;73(9):56-61.

10. World Health Organization, Global Alert and Response. Recommendations for influenza vaccine composition. Geneva: WHO. [Accessed 9 Jan 2012]. Available from: http://www.who. int/influenza/vaccines/virus/recommendations/en/

11. Gilca V, De Serres G, Hamelin M-E, Boivin G, Ouakki M, Boulianne N, et al. Antibody persistence and response to 20102011 trivalent influenza vaccine one year after a single dose of 2009 AS03-adjuvanted pandemic $\mathrm{H}_{1} \mathrm{~N}_{1}$ vaccine in children. Vaccine. 2011;30(1):35-41.

12. Scheifele DW, Dionne M, Ward B, Cooper C, Vanderkoo O, Dobson $S$, et al. Safety and immunogenicity of re-vaccination with $\mathrm{H}_{1} \mathrm{~N}_{1}$-containing 2010-2011 seasonal influenza vaccine after priming with 2009 adjuvanted pandemic vaccine. Proceedings of the 14 th Annual Conference on Vaccine Research, 16-18 May 2011, Baltimore, MD, Abstract S18.

13. Katoh K, Misawa K, Kuma K, Miyata T. MAFFT: A Novel Method for Rapid Multiple Sequence Alignment based on Fast Fourier Transform. Nucleic Acids Res. 2002;30(14):3059-66. 
14. Altschul SF, Madden TL, Schaffer AA, Zhang J, Zhang Z, Miller W, et al. Gapped BLAST and PSI-BLAST: a new generation of protein database search programs. Nucleic Acids Res. 1997;25(17):3389-402.

15. Bush RM, Bender CA, Subbarao K, Cox NJ, Fitch WM. Predicting the evolution of human influenza A. Science. 1999;286(5446):1921-5.

16. Price MN, Dehal PS, Arkin AP. FastTree 2: Approximately Maximum-Likelihood Trees for Large Alignments. PLoS One. 2010:5(3):e9490.

17. Committee for Proprietary Medicinal Products [CPMP]. Note for guidance on harmonization of requirements for influenza vaccines. London: European Agency for the Evaluation of Medicinal Products; 17 Mar 1997. CPMP/BWP/214/96(circular no. 96-0666):1-22.

18. Potter CW, Oxford JS. Determinants of immunity to influenza infection in man. Br Med Bull. 1979;35(1):69-75.

19. de Jong JC, Palache AM, Beyer WEP, Rimmelzwaan GF, Boon ACM, Osterhaus ADME. Haemagglutination-inhibiting antibody to influenza virus. In: Brown F, Haaheim LR, Schild GC, editors. Laboratory correlates of immunity to influenza - a reassessment. Dev Biol. Basel, Karger., 2003:115:63-73.

20. Ansaldi F, Bacilieri S, Banfi F, Durando P, Sticchi L, Icardi G, et al. Neutralizing and hemagglutination-inhibiting activities of antibodies elicited by the 2004-2005 influenza vaccine against drifted viruses. Clin Vaccine Immunol. 2006;13(1):162-4.

21. Ohmit SE, Petrie JG, Cross RT, Johnson E, Monto AS. Influenza hemagglutination-inhibition antibody titer as a correlate of vaccine-induced protection. J Infect Dis. 2011;204(12):1879-85.

22. Morens DM, Burke DS, Halstead SB. The wages of original antigenic sin. Emerg Infect Dis. 2010;16(6):1023-4.

23. Skowronski DM, Hottes TS, McElhaney JE, Janjua NZ, Sabaiduc $\mathrm{S}$, Chan T, et al. Immuno-epidemiologic correlates of pandemic $\mathrm{H}_{1} \mathrm{~N}_{1}$ surveillance observations: higher antibody and lower cell-mediated immune responses with advanced age. J Infect Dis. 2011;203(2):158-67.

24. Mikolajczyk RT, Akmatov MK, Rastin S, Kretzschmar M. Social contacts of school children and the transmission of respiratory-spread pathogens. Epidemiol Infect. 2008;136(6):813-22.

25. Thompson WW, Shay DK, Weintraub E, Brammer L, Cox $\mathrm{N}$, Anderson LJ, et al. Mortality associated with influenza and respiratory syncytial virus in the United States. JAMA. 2003;289(2):179-86. 